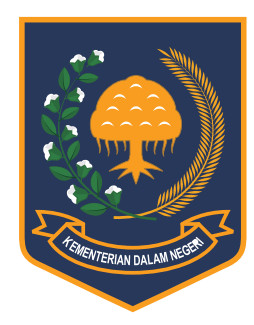

JURNAL BINA PRAJA

e-ISSN: 2503-3360 | p-ISSN: 2085-4323

Accreditation Number

21/E/KPT/2018

http://jurnal.kemendagri.go.id/index.php/jbp/index

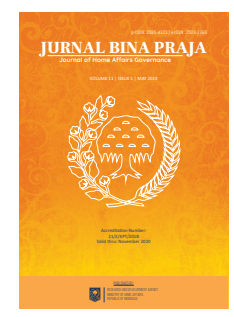

\title{
IMPLEMENTATION OF OLD Age InSURANCE POLICY IN INDONESIA
}

\author{
Putri Wijayanti*, Lina Miftahul Jannah \\ Faculty of Administrative Science \\ University of Indonesia \\ Komplek FISIP Universitas Indonesia, Jl. Prof. Dr. Selo Soemardjan, Depok, Jawa Barat 16424
}

Received: 10 June 2019; Accepted: 29 August 2019; Published online: 8 November 2019

DOI: $10.21787 /$ jbp.11.2019.185-195

\begin{abstract}
Old-Age Insurance (JHT), which is intended for workers entering the old age, is now widely claimed when workers are still in their early age discussing the implementation of the policy on benefits of Old Age Insurance (JHT) in Indonesia. This study discusses the implementation of policies on benefits of Old Age Insurance (JHT) in Indonesia. JHT is a program in the form of giving cash when participants enter retirement age. In its implementation, there are several obstacles, namely many participants who took the benefits of JHT at a young age. This has led to a shift in the philosophy of JHT as well as the existence of companies that register good programs, wages and labor. The purpose of this study is to analyze the implementation of the JHT benefit policy in Indonesia and what determines the success of implementing the JHT benefit policy. This study used a descriptive qualitative approach with data collection techniques through in-depth interviews and literature studies. In-depth interviews were conducted with several informants including the government, BPJS Employment, participants and employers as well as NGOs. The results of this study, namely the implementation of the JHT benefit policy in Indonesia goes well despite disharmony of regulations and the successful implementation of the JHT benefit policy in Indonesia is strongly influenced by various things including the content and context of the policy itself and compliance with implementers and factual sociological conditions of the community. The conclusion is that implementation is going well even though it still faces both regulatory and compliance constraints, so it needs to be revised PP 60 in 2015, the existence of unemployment benefits so that it does not interfere with JHT and innovative performance is needed from BPJS Ketenagakerjaan.
\end{abstract}

Keywords: Old Age Insurance, Social Security System, Worker Welfare, Worker.

\section{INTRODUCTION}

Employment is an important issue in Indonesia because $68.5 \%$ of the population is in the productive age group (Bappenas, 2018). The growth of productive-aged people is expected to grow into a reliable and competent workforce to be able to become a driver of development. Indonesian workers consist of formal and informal sector workers. Sakernas data in February 2018 shows that the total workforce is $127,067,835$ people, consisting of 53,094,391 people working in the formal sector, and $73,973,444$ people in the informal sector (BPS, 2018, pp. 1-10 ). The growth of the workforce, both in the formal and informal sectors, is the capital for Indonesia's development movement. Workers are entitled to fair remuneration, the fulfillment of social security, and rest periods. The government pays attention to the welfare of workers by reviewing wages annually, namely through the establishment of Regional / Provincial Minimum Wages (UMR / UMP). The important role of workers in the movement of the country's economy is pressuring the government to continue to pay attention to its welfare, including the necessities of a decent life for workers.

At work, a worker is not only entitled to a decent income, but also social security and benefits. Social protection will pay attention to social interventions that are formed to help individuals, households and communities to better manage risk and provide support to nearly poor people (Devereux, Stephen, and Wheeler, 2004, pp. 1-8). Social protection for workers in Indonesia has existed since 1992, marked by the issuance of Law

\footnotetext{
* Corresponding Author

Phone : +62817 76625442

Email : putri.wijayanti301@gmail.com
} 
Table 1.

Types of Claims for JHT Benefits in 2018

\begin{tabular}{|c|c|c|c|c|c|c|}
\hline \multirow{2}{*}{ Gender } & \multicolumn{6}{|c|}{ Number of Cases } \\
\hline & July & August & Sept & Oct & Nov & Dec \\
\hline Resign & 846,795 & 971,046 & $1,096,550$ & $1,239,640$ & $1,372,042$ & $1,487,572$ \\
\hline Laid-off & 176,132 & 202,704 & 227,998 & 255,967 & 281,681 & 303,825 \\
\hline Leave Indonesia & 2,697 & 3,123 & 3,559 & 3,986 & 4,382 & 4,783 \\
\hline 5-year 1 month & 89 & 103 & 107 & 110 & 120 & 123 \\
\hline 10 years membership & 17,430 & 19,865 & 22,416 & 25,437 & 28,391 & 30,702 \\
\hline Pension Fund & 31,225 & 36,057 & 40,738 & 45,928 & 50,398 & 54,136 \\
\hline Permanent Total Disability & 21 & 25 & 28 & 30 & 37 & 41 \\
\hline Death & 16,064 & 18,672 & 21,148 & 24,056 & 26,767 & 29,064 \\
\hline Change of Status & 2 & 2 & 2 & 2 & 2 & 2 \\
\hline Resign & 846,795 & 971,046 & $1,096,550$ & $1,239,640$ & $1,372,042$ & $1,487,572$ \\
\hline Laid-off & 176,132 & 202,704 & 227,998 & 255,967 & 281,681 & 303,825 \\
\hline Leave Indonesia & 2,697 & 3,123 & 3,559 & 3,986 & 4,382 & 4,783 \\
\hline
\end{tabular}

Source: Processed data from the BPJS Employment Report, 2018

No. 3 of 1992 on Workers' Social Security. In 1992, the Manpower Social Security Act had 5 programs for workers, namely the Health Care Insurance Program, the Work Accident Insurance Program, the Death Insurance Program, the Old-Age Insurance Program, and the Pension Insurance Program. Social protection for these workers is managed by PT. Jamsostek, which is a profit-oriented company. Law No. 13 of 2003 on Employment explains that workers have the rights to obtain protection for occupational safety and health, morals and decency, treatment following human dignity and values, and religious values. Article 99 paragraph (1) of the Manpower Act further stipulates that workers and their families have the rights to obtain worker social security. This emphasizes that social security for workers is important to protect workers from unwanted possibilities/ occupational risks.

In 2004, there was a reform to social security regulations. This is marked by the issuance of Law Number 40 of 2004 on the National Social Security System (SJSN Law). Fundamental changes to labor social security include participation in getting social security benefits, not only for formal workers but also for informal workers. The government stipulates that all workers must join the social security for workers with gradual participation. This regulation confirms that workers' social security in Indonesia is currently organized by the Employment Social Security Organizing Agency (BPJS Employment), which is a public legal entity and organizes 4 programs, namely (i) the workplace accident security Program (JKK), (ii) death security program (JKM), (iii) Old Age Security Program (JHT) and (iv) Pension Security Program (JP). This social security protects workers, both at work and entering retirement (post-work), with the allotment of protection and welfare. Social Security is the rights of workers to avoid workers from poverty when things go wrong/risky.

Since the issuance of the SJSN Law, policymakers have tried to align the objectives of the JHT program which can provide substantial benefits when workers enter old age or retire. The Implementing Regulation of the SJSN Law, namely Government Regulation Number 46 of 2015 on the Implementation of the Old Age Security Program explains the benefits of the JHT Program in the form of cash that can be paid at once when participants enter retirement age, die, or experience permanent total disability. Based on this, the payment of JHT benefits is following the mandate of the SJSN 
Law. Government Regulation Number 46 of 2015 further explains the existence of other additional benefits from JHT funds, namely $10 \%$ for retirement preparation needs, and 30\% for housing after 10 year membership.

The SJSN Law and Government Regulation Number 46 of 2015 received strong protests from the community because of policies that were considered burdensome to the community. The role of the Workers Union Association is very vital in threatening to hold a large demonstration if the Government did not immediately revise the Government Regulation on JHT (https:// www. kompas.com, 2015).

The community was listened to by the government and issued a policy that updated the previous policy, but in the end, the policy issued was not following the laws and regulations above it, namely the SJSN Law.

In the explanation of the Government Regulation Number 60 of 2015, it is stated that pension includes work termination. This emphasizes that the benefits of the JHT program can be disbursed when workers stop working even though they have not yet entered retirement age. The Regulation of the Minister of Manpower Number 19 of 2015 on Procedures and Requirements for the Payment of Old Age Benefits, which is an implementing regulation of Government Regulation Number 60 of 2015, which further explains about stop working, including participants resigning, laying off, and leaving Indonesia forever.

The resignation claim type is the highest among others, this can be seen in table 1 above. JHT implementing regulation contradicts the SJSN Law and have been discussed in previous research (Ariesta, 2016, pp. 101-103). Minister of Manpower Regulation No. 19 of 2015 provides easy conditions for those who are laid off and resigned to take advantage of JHT, even though they are still in their productive age.

JHT fund claims for the reason of participants quitting their job, as referred to in the Minister's Regulation (Permenaker) Number 19 of 2015, are due to resignation, dismissal, and leaving the Republic of Indonesia as the top figures in the payment of benefits in the JHT program. This is a problem because it results in reduced or even loss of cash benefits that should be received by participants when entering retirement age, death, or total disability. There is research that discusses oldage insurance in Thailand, which in the end has not been able to reduce poverty in old age (Chalamwong \& Meepien, 2013). This emphasizes that savings withdrawn in old age alone cannot provide poverty alleviation for old age. Also, previous research stated that Permenaker Number 19 of 2015 conflicts with the SJSN Law (Ariesta, 2016). Another research on the implementation of the employment social security program in Manado emphasizes that communication, disposition, and structure of the BPJS is good but needs to add resources and improve services. Besides, JHT research has also discussed the implementation of the JHT Program of BPJS Employment at PT YPTI Yogyakarta (Samba Rufus, 2016) but uses an analysis of legal behavior theory.

This study is interesting because no one has discussed the implementation of the old-age insurance policy in Indonesia that uses Grindle's policy implementation theory. Grindle (1980) emphasizes that policy implementation can be seen in terms of the content and context of the policy itself. The policy content includes the influencing interests, the type of benefits, the degree of change desired, the location of decision making, program implementers, and resources. For the context (environment) policy includes the power and strategy of the actors involved, the characteristics of the authorities, and the level of compliance.

The JHT benefits have significant problems, both in terms of government regulations and the compliance of the implementers, so that the JHT benefits cannot be optimally accepted by the participants. The disharmony regulation from Permenaker 19 of 2015 makes participants lose collateral in their old age. The governance of JHT benefits policy also has its problems. Based on this, this research will discuss the implementation of the old-age insurance policy in Indonesia and the things that determine the implementation of the old-age insurance policy in Indonesia.

\section{METHOD}

This study uses a post-positivist approach with qualitative data collection methods because it explores and understands the meaning that several individuals or groups of people ascribe to social or humanitarian problems and uses theory as a reference but not to prove.

This research is a type of descriptive research because it has the aim to provide a detailed picture of a situation that occurs, both by looking at the situation, social background and the relationship between actors, as well as the implementers associated with implementing the benefits of the JHT program. Data collection/collection techniques are carried out through in-depth interviews and literature studies. The data analysis technique uses qualitative data analysis technique, namely the illustrative method. According to Neuman (Neuman, 2001, pp. 131), the illustrative method 
links theoretical concepts with empirical evidence. This study uses the illustration method because it links the existing theories with the conditions in the field. This research was conducted for 2 months from April-May 2019.

\section{RESULTS AND DISCUSSION}

The research on old age savings has been done before but analyzed in terms of legal jurisdiction (Ariesta, 2016 and Lemek, 2016). This is as stated by Lemek (2016) that the application of JHT claims puts forward the purpose of the law to provide a sense of justice and benefit to the community but cannot provide legal certainty.

Based on this, legal certainty is not achieved because implementing regulations conflict with the SJSN Law. Besides, this condition results in many claims.

The application of JHT in Indonesia is different from that in Thailand which emphasizes that JHT is only in the form of savings that can be taken when reaching old age. For this condition, even Thailand has not been able to get its people out of poverty (Chalamwong \& Meepien, 2013, pp. 230). The Philippines has so far not been able to cover the full social security of its workers due to difficulties in reaching the informal sector (Ramesh, 2015, pp. 40-56). For China, the attention is starting to extend to JHT granting from the urban sphere to reaching the countryside (Qin et al., 2015, pp 1047-1066). The birth of the market economy in China made the government must build a system for the welfare of workers (Watson, 2012, pp 265-287). Old age insurance is considered the right thing to save elderly people from poverty even though there are still many obstacles facing both policies and increased benefits (Pamela Herd, Melissa Favreault, Madonna Harrington Meyer, \& Timothy M. Smeeding, 2018) and an increase in personal savings in old age for the future.

The United States puts social security as the most important program, one of which is by providing a primary source of income for those who have retired (Turner, 2013, pp. 1-10). One article mentioned that elderly data record is needed. Pension reform over the past decade has strengthened the importance of the second and third pillars, thus increasing the importance of workplace pensions and personal savings for future retirement income (Mika, Tatjana, Rehfeld, 2010, pp. 1-10). At present, Indonesia does not only think of old-age insurance for formal workers but also informal workers. This is also what China has done in reforming the social welfare system in 2002 and has expanded the scope and protection of vulnerable populations. (Carrillo, 2017, pp. 28-31). Existing policies are expected to provide benefits for those who have been considered forgotten. Noteboom (Nooteboom \& Nooteboom, 2014 pp. 280-293) explains that it is important to think about social security for those who are poor.

\section{A. Implementation of JHT Benefits Policy}

The implementation of the JHT benefits policy in Indonesia has been going on for a long time before the SJSN era, as stated by Ms. Haiyani Rumondang as the Director-General of Industrial Relations and Social Security Development:

This JHT has been around for a long time since 1992 but in 2004, through the SJSN Law, was renewed with a 10-year membership and can be taken for housing and retirement preparation but the demands of workers to make PP 46 in 2016 must be revised to PP $60 / 2015$, it should be distinguished between resigning and laid off.

Based on the things mentioned, by referring to what was stated (Grindle, 1980, pp. 1-13) that implementation is a general process of administrative action that can be examined at a particular program level. Grindle also emphasized that policy implementation is a political and administrative process of a government. Policy implementation can begin when targets have been set, program activities have been well structured, and funding has been allocated to achieve goals. This is like what happened in the implementation of JHT benefits policy in Indonesia which is also a political process to produce regulations that are currently being applied. In Indonesia, the implementation of the benefits policy can be said to have gone well but still faces various obstacles both in terms of regulation and compliance from the various actors involved. PP 60 of 2015 provides a loophole for workers who resign to be able to disburse the benefits of JHT even though the Ministry of Labor emphasizes that there must be a difference between resigning and downsizing. The condition of resignation is a planned condition different from downsizing which is a condition where workers are not ready so that support is needed to avoid the risk of loss of income.

According to Grindle (1980) policy implementation is an interesting thing to discuss because its development includes political movements and government administration. This is what happened to the JHT benefits policy with demands and mass mobilization to suppress the 
revision of PP no. 46 of 2015.

The public policy expressed by Anderson is everything that the government does or does not do (Anderson, 2011, pp. 1-33). This is as, in this study, public policy regarding the benefits of JHT is an action taken by the government to implement the principle of compulsory savings intended for workers who are entering retirement age. Thomas Dye further explained that public policy regarding government decisions on anything to choose to do or not do (Dye, 2013, pp. 3-7). This is what the Indonesian government did in response to the shift in JHT philosophy. The implementation of JHT has existed since 1992 with the issuance of Law Number 3 of 1992 concerning worker social security so that all workers are required to have Jamsostek. In the SJSN era marked by the issuance of Law Number 40 of 2004 on the Social Security Act, then social security became compulsory for workers in both formal and informal sectors. This policy of providing social security benefits is a government action to protect workers in Indonesia. In the implementation of the JHT benefits policy in accordance with PP $46 / 2015$, social unrest occurs in the community when workers demand that JHT benefits can be returned to as managed by PT Jamsostek, namely 5 years membership, and there are even tougher demands that JHT must be disbursed at any time when quitting work because it is for the savings of the worker. In this condition, according to Dye's public policy theory, the Government chose to do according to respond to demands through the revision of PP $46 / 2015$ so that PP $60 / 2015$ was published. For now, there are more demands that JHT should be returned to 5 years membership so not all workers withdraw the money by the time of the layoffs or resign, the government chose not to do it because it is still contrary to the SJSN Law. This shows that all actions of the government, both doing and not doing something, is a form of public policy.

After a public policy is determined, according to William Dunn (Dunn, 2003, pp. 1-38) that the policy will not have an impact and cannot achieve the objectives of the policy itself if the policy is not implemented. This is under the conditions if the JHT benefit policy in Indonesia is not implemented then there are no participants as beneficiaries who can receive JHT benefits. This shows that no matter how good the policy is, it will never be useful if not implemented. This is as stated that the important process in a policy is the implementation of the policy itself. The importance of policy implementation is reinforced again by Pressman and Wildavsky explaining "policy implementation may be viewed as a process of interaction between the settings of goals and actions geared to achieved them" that policy implementation is a process of interaction between goals and actions taken to achieve these goals. The objectives that have been compiled will be realized through various activities, can be in programs to support the achievement of objectives so that implementation as a process becomes important for achieving the objectives of the policy. This can explain the implementation of the JHT benefits policy which is realized as a whole through the implementation of the JHT program under the SJSN Law which emphasizes that JHT benefits can be given to participants entering retirement age, total disability, and death. The SJSN Law is implemented through PP 46/2015 which confirms that JHT benefits can be given to participants who are entering retirement age, total disability, and death and are given leeway to take after 10 years membership with a magnitude of $10 \%$ for retirement preparation and $30 \%$ for housing ownership.

The results of an interview with Timboel Siregar as the Coordinator of the BPJS Watch stated that at the moment the Workers' union demands to return to the previous JHT conditions which refer to the Labor Social Security Act of 1992 which emphasizes taking JHT benefits on membership for 5 years 1 month. Timboel added that there were shortcomings in the SJSN Law because it did not regulate certain conditions in withdrawing JHT benefits. In the 1992 Social Security Act, certain conditions are defined as taking benefits from JHT with conditions of participation for 5 years and 1 month. Timboel believes that the policies taken by the government are populist and ultimately have wide-ranging effects. The role of the Workers Union Association is very large by threatening to hold a large demonstration if the Government does not immediately revise the Government Regulation on JHT (https:// www.kompas.com, 2015).

In an interview conducted with Plt. Secretary of the National Social Security Board (DJSN), Linda Darnel explained the claim that occurred in a large scale in July 2015 due to the absence of a transition period from the JHT benefit policy itself so workers were worried that JHT funds could not be taken back. Linda Darnel also emphasized that the SJSN Law does not include discussion of certain conditions, which means the taking of JHT benefits for 5 years and 1-month membership because it wants to emphasize that JHT is a guarantee intended when participants enter retirement age. This shows that JHT is intended for participants entering retirement age or experiencing risks that result in loss of income. This also has an impact on the continuous withdrawal of JHT funds and the difficulty of implementing the development of JHT 
funds over a long period so that the return on the development of JHT funds to participants cannot be optimal.

Ahmad Ansyori as a Member of the DJSN from the expert element added that currently, BPJS Employment has not yet had a target for developing JHT funds so it is still fixated with a percentage that is considered safe because it is still above deposit interest. BPJS Employment must innovate to provide good funding development so that the 9th SJSN principle, namely, to provide maximum benefits for participants can be achieved. The disharmony of regulations from the Minister of Manpower against Government Regulation Number 46 of 2015 and the SJSN Law has become a phenomenon born of a policy implementation involving various actors and implementers. Implementation of the benefits policy from JHT certainly involves many actors, strategies, pressures, and the character of the decision-maker. Ms. Haiyani Rumondang as Director-General of Industrial Relations and Social Security Development, the Ministry of Manpower needs to emphasize that regulatory errors are not in Permenaker No. 19/2015 because Permenaker only refers to PP 60 of 2015. The Workers Union is considered inconsistent in determining attitudes because in 2015 when PP 46 of 2015 was carried out by the Workers Union to insist that JHT can be disbursed at any time, considering that quit working is a vulnerable condition to provide support. The Director-General of PHI and Jamsos explained that JHT should be returned to the SJSN Marwah.

The discussion about the shift in the philosophy of JHT benefits, which causes a shift in the philosophy of JHT itself, is based on not being separated from social security for workers who want to be provided by the Government. Decisions obtained by the government are inseparable to ensure the survival of workers when workers experience income loss, but even making these decisions is considered inappropriate for DJSN and BPJS Watch so there is a need for a review. The implementation of Government Regulation No. $46 / 2015$ is considered the most appropriate for now. This condition makes the withdrawal of JHT for those who resign becomes the highest claim and indicates the existence of fraud such as the existence of workers who deliberately resigned to withdraw JHT and then re-enrolled in the same company. For the time being, the Workers Unions are asking to be returned to 5-year membership to take JHT benefits. This is certainly not following the National Social Security System Law. Evaluating the interaction between increasing life expectancy and changing age patterns in work participation from a planning perspective for an aging population is important as in India (Dhillon \& Ladusingh, 2013, pp. 733-762).

At present, many elderly people have a good level of health so that they are still able to work. This indicates the need for a review of retirement age. One challenge for developed countries is overcoming an aging population. One way to overcome this is to increase the normal retirement age (Scherbov, Sanderson, \& Mamolo, 2014, pp. 579-608). This shows an improvement in life expectancy, so it is necessary to examine the possibility of retirement age to be changed to meet the needs and reduce the burden on both the government and dependence on those who are productive.

\section{B. Things That Determine the Successful Implementation of JHT Benefits Policy}

Grindle states that policy implementation is a political and administrative process of government (Nugroho, 2014). Policy implementation can begin when targets have been set, program activities have been well structured, and funding has been allocated to achieve goals.

The implementation of the JHT benefits policy can achieve its objectives if the actions taken are correct in the implementation of the policy. According to Grindle, the success of public policy implementation is determined by the level of implementation of the policy itself, which consists of Content of Policy and Context of Policy. The contents of the policy (Content of policy) include the following:

\section{1) Content of Policy}

- Interests that influence

Grindle said that the implementation of policies is the result of a political process that prioritizes its respective interests. This is what happens in the implementation of the JHT benefits policy, some interests affect the interests of workers, the interests of employers, and the interests of the government. Workers want a guarantee when they retire to prepare for their old age. The employer shares the burden of contributions to workers to deposit workers' compulsory savings.

The contribution of the JHT Program according to the SJSN Law and implementing regulations below is $5.7 \%$ of the salary/wages registered for formal and for informal sector workers, it is according to the salary/ wages registered and the type of work. Informal sector workers, employers bear $3.7 \%$ and workers $2 \%$. The government has an interest in ensuring that Indonesian workers have collateral when they enter old age or reach retirement. This interest implements the policy still 
Table 2.

The Number of Social Security Insurance Membership 20152018 Table

\begin{tabular}{|c|c|c|c|}
\hline \multirow{2}{*}{$\begin{array}{c}\text { Participant } \\
\text { Segment }\end{array}$} & \multicolumn{3}{|c|}{ Number of Participants } \\
\hline & 2016 & 2017 & 2018 \\
\hline \multicolumn{4}{|c|}{ JKK/JKM } \\
\hline PPU & $14,571,791$ & $16,068,453$ & $19,427,150$ \\
\hline BPU & $1,379,072$ & $1,714,169$ & $2,393,022$ \\
\hline Jakon & $6,682,219$ & $8,459,410$ & $8,639,900$ \\
\hline Total JKK/JKM & $22,633,082$ & $26,242,032$ & $30,460,072$ \\
\hline \multicolumn{4}{|c|}{ JHT } \\
\hline PPU & $13,677,912$ & $14,427,135$ & $15,270,335$ \\
\hline PBPU & 95,167 & 143,148 & 206,392 \\
\hline Total JHT & $13,773,079$ & $14,570,283$ & $15,476,727$ \\
\hline \multicolumn{4}{|c|}{$J P$} \\
\hline PPU & $9,130,671$ & $10,633,387$ & $11,846,051$ \\
\hline
\end{tabular}

Source: Processed Data from the 2018 BPJS Employment Report

work because workers need welfare, employers need optimal performance from sound workers, and the government needs the government to realize the welfare of its people especially when the income decreases in old age. This, of course, will reduce the level of dependency costs of the elderly population to the productive age population.

\section{- Benefit Type}

Every policy is required to have benefits (Grindle, 1980, pp. 1-42). This also applies to the JHT benefits policy which has great benefits for the welfare of workers when entering old age. Based on the SJSN Law, which was passed down through PP Number 46 of 2015, JHT benefits are in the form of cash given to participants when participants enter retirement age, Total disability, and death. Ahmad Ansyori explained as follows: "Every human being, including workers, will certainly experience old age so it is necessary to provide guarantees to participants when they enter retirement age." The funds can be used to resolve things that have not been resolved at work or even become initial capital for workers entering the new world."
- Degree of Change to Be Achieved

Grindle (1980) revealed that every policy must have success targets so that it is clear the change to be achieved. The change to be achieved by the JHT benefits policy is the provision of old-age benefits to all workers in both the formal and informal sectors. Another change to be achieved is to increase participants' awareness of the importance of having compulsory savings that can be used in their old age so that the preparation for retirement can be more mature and secure with mandatory membership. Before the SJSN was born, JHT benefits were only owned by formal workers. This was responded with an increase in the participation of social security in employment, including JHT programs. JHT program membership has increased from year to year. Since the issuance of Law Number 40 of 2004 on the National Social Security System (the SJSN Law), a membership in old-age insurance is carried out in stages and 2029, it is targeted to achieve universal coverage in Indonesia. In 2014, there were $12,724,248$ JHT program participants and then increased in 2015 to $13,154,786$ people. In 2016, JHT program membership reached 13,773,079 and then in 2017, it reached 14,570,283. Increased membership in the JHT program also includes formal and informal sector workers (BPJS, 2017, 1-2). The degree of change in the benefits policy has seen an increase in formal sector workers in Table 3.

Table 3.

Social Security Insurance Membership Segments

\begin{tabular}{lrrr}
$\begin{array}{l}\text { Participant } \\
\text { Segment }\end{array}$ & \multicolumn{2}{c}{$\mathbf{2 0 1 6}$} & \multicolumn{2}{l}{$\mathbf{2 0 1 7}$} & \multicolumn{1}{l}{2018} \\
\multicolumn{4}{c}{ JKK/JKM } \\
\hline PPU & $14,571,791$ & $16,068,453$ & $19,427,150$ \\
\hline BPU & $1,379,072$ & $1,714,169$ & $2,393,022$ \\
\hline Jakon & $6,682,219$ & $8,459,410$ & $8,639,900$ \\
\hline Total JKK/JKM & $22,633,082$ & $26,242,032$ & $30,460,072$ \\
\hline & JHT & & \\
\hline PPU & $13,677,912$ & $14,427,135$ & $15,270,335$ \\
\hline PBPU & 95,167 & 143,148 & 206,392 \\
\hline Total JHT & $13,773,079$ & $14,570,283$ & $15,476,727$ \\
\hline & & & \\
\hline PPU & $9,130,671$ & $10,633,387$ & $11,846,051$ \\
\hline
\end{tabular}

Source: BPJS Employment, 2018 
Based on these data, there was an increase in BPU from 2016 to 2018 for JHT benefits to reach 206,392 workers.

\section{- Decision-Making Position}

In his interview, Subiyanto, as a representative of the Workers Unions, said that JHT should be returned to the SJSN Law with 10 years of membership and for those who were laid off and resigned, there should be something like training or unemployment benefits to sustain worker's life when not working.

According to Grindle (Grindle, 1980, pp. 1-42), the position of decision making determines the success of the implementation of the policy itself. For now, the JHT benefits policy is still considered inappropriate because of the layoffs of workers who have been laid off, especially those who have resigned first, to JHT beneficiaries. The decision that came because of the workers' demands sociologically accommodated the needs of the participants, but it was contrary to the philosophical and even legal aspects of the policies above. This is consistent with what Grindle said that the decision making regarding the revision of PP 46/2015 presents its logical consequence that many productive ages have disbursed the benefits of JHT. Old age insurance as a form of protection puts forward the togetherness of all workers to be able to enjoy a better old age even though there are risks that must be carried. This is as stated by Veen (Veen, 2012, pp. 14-15) that social security carries both risk and solidarity.

\section{- Program Implementers}

The implementers of the JHT program is BPJS Employment. BPJS Employment has an important role in the realization of the 9 th principle of the National Social Security System, namely, the management of the National Social Security Fund is used entirely for program development and for the maximum benefit of the participants. Ahmad Ansyori as a Member of the DJSN said that the current regulation only accommodates that JHT development funds must be above the deposit interest. BPJS Employment should have a target of developing JHT program funds with a fixed figure for example $5 \%$ of deposit interest or more so that BPJS Employment can create conditions that are optimal for the development of participants' mandatory savings results. This is done by promoting the principle of caution. Also, BPJS Employment is seen as having good capabilities in performance, this is indicated by the presence of several awards that are included in the good performance appraisal category determined by the DJSN. At present, BPJS Employment manages very large assets, which can
Table 4.

The Table on The Achievement of Social Security Assets as of 31 December 2017

\begin{tabular}{ccc} 
Aset & $\mathbf{2 0 1 6}$ & $\mathbf{2 0 1 7}$ \\
JKK & $18,973,789,484,903$ & $24,120,807,511,671$ \\
\hline JKM & $6,362,652,956,249$ & $8,346,200,788,737$ \\
\hline JHT & $217,708,044,409,357$ & $254,208,066,437,198$ \\
\hline JP & $12,195,006,215,997$ & $25,667,069,388,586$ \\
\hline
\end{tabular}

Source: Researcher Processed Data based on BPJS Employment Financial Statements, 2017

be seen in Table 4.

Based on the data above, it can be seen that the largest assets are found in the Old Age Insurance (JHT) program, this emphasizes that good asset management can be beneficial for optimal returns for participants.

According to Grindle (1980), the success of policy implementation is also determined by reliable implementers so that they have good and appropriate competence in implementing policies. This is related to the capability of BPJS Employment to be good and is a public legal entity which is the result of a transformation from PT Jamsostek. This company has had experience since 1992 so that its competence is not in doubt. This of course also must pay attention that there are still many cultures that need to be changed because of the changing institution, which is a profit-oriented body which then becomes a public legal entity. BPJS Employment must be able to innovate more in investment placement to provide a large return for participants by prioritizing the principle of prudence. BPJS Employment currently still allocates very little development funds to the stock market because the risk of concern is too great.

This implementer influences the implementation of the JHT benefits policy. BPJS Employment as the organizer must be able to innovate to attract interest while increasing the awareness of workers and employers to register themselves in the workers' social security program, one of which is JHT.

- Resources

At present, BPJS Employment has a BPJSTK application to make it easier for participants to check the JHT balance.

The implementation of the JHT benefits policy does not exist without the use of well-used resources. Existing resources are the adequacy of 
funding, understanding, employees who perform well, adequate IT systems, good regulation, and so on.

\section{2) Context of Policy (Policy Environment)}

- The Power, Interests, and Strategies of the Actors Involved

The implementation of the JHT benefits policy is influenced by the power, interests, and strategies of the actors involved. This is marked by the movement of Workers Unions that demand changes in the period of participation for withdrawing the benefits of JHT. The results of an interview with Mr. Andi Awaluddin as Head of the Sub Directorate for Social Security, to accommodate workers' demands, various ministries, including the Ministry of Manpower and the Ministry of Law and Human Rights, worked together to conduct discussions so a decision was made to revise PP $46 / 2015$. The decision was made to maintain social and economic stability. The statement added that in its implementation, there were gaps to workers who resigned and caused many productive ages to withdraw JHT.

- Characteristics of institutions and ruling regimes

The characteristics of the ruling regime is an important influence in the implementation of JHT benefits policy. The Indonesian government gives full support and attention to the welfare of workers. The current regime is concerned with the needs of workers in obtaining social security and cash can be obtained for retirement. A regime can decide whether or not a policy continues. The characteristics of the ruling regime are very strong to influence the implementation of JHT benefits policy in Indonesia. Workers' demands to return to the JHT benefits withdrawing to be like the implementation of PT JAMSOSTEK, namely membership for 5 years and 1 month, can even be taken at any time and are expected to be able to accommodate the guarantee for those who stop working. The Government through the Minister of Manpower Regulation No. 19 of 2015 decided that the benefits of JHT can be taken at any time when workers stop working, which is defined as being laid off and resigning. The government's strategy has a very significant influence on the implementation of the JHT benefits policy itself, both in terms of regulation, and management for the development of JHT funds.
- Compliance and Responsiveness of the Implementers

Based on Article 11 of Law Number 24 of 2011 on BPJS, one of the authorities of BPJS is to supervise and examine the compliance of Participants and Employers in fulfilling their obligations per the provisions of the national social security legislation. Many employers still do Partial List Companies (PDS) for wages, programs, and labor. Following the data in table 3.1. JKK/JKM membership is much higher than the JHT. This shows that not all companies register all programs with their employees. Currently, BPJS Employment performs its duties and functions by and organizes JHT programs based on JHT benefits policy, namely Permenaker No. 19 of 2015. BPJS as the organizer, which adheres to performance, targets and responds to high enthusiasm in JHT claims. BPJS Employment facilitates participants by providing an online system for each claim and monitoring the JHT balance. Compliance and the existence of response from the labor BPJS provides a space for ongoing implementation of the JHT benefits policy for participants.

Grindle put forward the view of policy implementation through a chain of command so that the thought of top-down implementation is very inherent in the factors that determine policy implementation. Rippley and Franklin try to emphasize that policy implementation is not only seen as a command but more than that, it is necessary to pay attention to the views of individuals and organizations.

The theory discussed by Rippley and Franklin (in Winarno, 2014) is Hybrid which is a combination of a top-down and bottom-up model of policy implementation. The implementation of the JHT policy cannot only be seen from the side of the government but also sees the perspective of workers as participants. Workers are aware of the need to disburse JHT funds when laid off, but they are starting to realize that JHT is placed as a Certain Day Guarantee and it is not the right policy to place JHT. Rippley and Franklin saw implementation through a compliance approach and factual approach.

Compliance approach sees BPJS employment must comply with established regulations, including to collect social security funds under applicable regulations. This confirms that BPJS has an important role in the successful implementation of JHT benefits because it can anticipate the existence of a partial list company (PDS) in terms of programs, wages, and labor. For a factual approach, which is sociological, workers have a concern not only of losing income in old age but at a productive age. This results in workers being deemed forced to withdraw the benefits of JHT when laid off even though they are 
still in their productive age. According to Subiyanto, representatives from unions said that social security when not working or unemployment benefits. This is like the United States who paid temporary income support for experienced workers who lose their jobs not because of their fault (Wandner, 2018, pp. 1-21). Eligibility is a matter that must be considered so that workers can work again (O'Leary, Christopher J., and Wandner, 2018, pp. 131-135).

This unemployment benefit must exist to support workers who have been laid off so that they can help their lives to be able to work again. This should not be taken from JHT funds so that JHT funds can still be received by participants when entering retirement age.

\section{Conclusion}

The current implementation of JHT benefits policy is inseparable from the influence of the content and context of the policy itself. The withdrawal of JHT funds at productive age in the implementation of the policy is influenced by the interests of workers to be able to disburse benefits and be supported by the government who decided to revise Article no. 26 of Permenaker No. 46 of 2015 so that the contents of the policy affect the current policy implementation. The policy context also influences the current implementation of the policy because high claims on resignation are inseparable from government support to protect those at risk of loss of income and BPJS compliance to continue carrying out their duties. Besides, the power and strategy of the participants, as well as the objectives of this policy, give strength to the implementation of this policy so that even though it is not under the SJSN Law, it still runs. The existence of this high claim number is inseparable from the participant's strategy which has started to attract at a young age, they feel the need for support funds when facing the risk of loss of income, there are also those who worry that policies will change and funds cannot be taken so they decide to take benefits early.

Based on this research, it is suggested to the Government to return JHT to its original philosophy so that Government Regulation Number 60 of 2015 needs to be revoked to realize synchronization of regulations. The government can also consider the existence of policies for workers who are laid off and resign separately from JHT so that there is an unemployment benefit policy to provide protection when workers lose income and provide training/ soft skills for the needs of Indonesian human resources in the face of world uncertainty. Besides, the BPJS Employment that has been transformed from before PT Jamsostek (Putri, 2014, pp. 1-5) needs to make innovative and creative efforts to be able to develop Additional Service Benefits (MLT) so that it can attract workers to become participants. BPJS Employment needs to be more assertive in exercising authority, namely collecting payment fees and conducting supervision and inspection of Participants and Employers' compliance in fulfilling their obligations so that there are no receivables.

\section{ACKNOWLEDgMENT}

The author would like to thank BPJS Employment, the National Social Security Board (DJSN), the Director-General of Industrial Relations and Social Security Development, the Directorate of Social Security, BPJS Watch, and to all parties who cannot be mentioned one by one. The author also thanks the reviewer for providing all useful review results.

\section{REFERENCES}

Anderson, J. E. (2011). Public Policy Making (seventh ed; C. Merrill, Ed.). United States: Suzanne Jeans, Texas A\&M University.

Ariesta, A. (2016). Penyelenggaraan Program Jaminan Hari Tua (Analisis Yuridisterhadap Peraturan Pemerintah Nomor 46 Tahun 2015 tentang Penyelenggaraan Program Jaminan Hari Tua dan Peraturan Pemerintah Nomor 60 Tahun 2015 tentang Perubahan atas Peraturan 46 Tahun 2015 tentan. Universitas Indonesia.

BPJS. (2017). Keuangan konsolidasian tahun 2017.

BPS. (2018). Keadaan Ketenagakerjaan Indonesia February 2018. Badan Pusat Statistik, (42), 1-16. https://doi.org/No. 74/11/35/Th.XVI, 5 November 2018

Carrillo, B. (2017). Migrant Labour and the Sustainability of China's Welfare System. Disturbances in Heaven, 28-31. https://doi. org/10.22459/mic.02.2017.05

Chalamwong, Y., \& Meepien, J. (2013). Poverty and Just Social Protection in Thailand. ASEAN Economic Bulletin, 29(3), 230. https://doi. org/10.1355/ae29-3e

Devereux, Stephen dan Wheeler, R. S. (2004). Transformative Social Problem. In Health Policy and Planning (No. IDS Working Paper 232). https://doi.org/10.11694/pamj. supp.2014.17.1.3205

Dhillon, P., \& Ladusingh, L. (2013). Working life gain from gain in old age life expectancy in India. Demographic Research, 28(June 2013), 733-762. https://doi.org/10.4054/ DemRes.2013.28.26

Dunn, W. N. (2003). Pengantar Analisis Kebijakan Pulblik-Gadjah Mada University Press (M. 
Darwin, Ed.). Yogyakarta: Gajah Mada University Press.

Dye, T. R. (2013). Why You Need This New Edition Six good reasons why you should buy this (14th ed.; L. Dorson, Ed.). United State: Pearson Education.

Grindle, M. S. (1980). Politics and Policy Implementation in The Third World. In M. S. Grindle (Ed.), Princeton University Press. New Jersey: Princeton University Press.

Mika, Tatjana, Rehfeld, U. dan S. M. (2010). Income Provisions and Retirement in Old Age. Jstor, (Old Age), 1110-1113. Retrieved from https:// www.jstor.org/stable/j.ctvbkk43d.70

Neuman, L. (2001). Basics of Social Research: Qualitative \& Quantitative Approaches. In Pearson Education Limited (3th ed.). London: Pearson Education.

Nooteboom, G., \& Nooteboom, G. (2014). Conclusion: Forgotten people?: Poverty, Risk and Social Security in Indonesia. Forgotten People: Poverty, Risk and Social Security in Indonesia, 280-293. https://doi. org/10.1163/9789004282988_010

O'Leary, Christopher J., and Wandner, S. A. (2018). Unemployment Insurance Reform: EvidenceBased Policy Recommendations Chapter. Unemployment Insurance Reform, 131-135. Retrieved from https://www.jstor.org/ stable/j.ctvh4zfsf.8

Pamela Herd, Melissa Favreault, Madonna Harrington Meyer, \& Timothy M. Smeeding. (2018). A Targeted Minimum Benefit Plan: A New Proposal to Reduce Poverty Among Older Social Security Recipients. RSF: The Russell Sage Foundation Journal of the Social Sciences, 4(2), 74. https://doi.org/10.7758/rsf.2018.4.2.04

Putri, A. E. (2014). Paham Transformasi Jaminan Sosial Indonesia (Pertama). Jakarta: Friedrich-
Ebert-Stiftung.

Qin, M., Zhuang, Y., \& Liu, H. (2015). Old age insurance participation among rural-urban migrants in China. Demographic Research, 33(1), 1047-1066. https://doi.org/10.4054/ DemRes.2015.33.37

Ramesh, M. (2015). Social Protection in Indonesia and the Philippines: Work in Progress. Southeast Asian Economies, 31(1), 40-56. https://doi.org/10.1355/ae31-1c

Samba Rufus, E. (2016). Jurnal Pelaksanaan Bpjs Ketenagakerjaan Program Jaminan Hari Tua (JHT) Di Pt. Yogya Presisi Tehniktama Industri (Ypti) Di Yogyakarta.

Scherbov, S., Sanderson, W. C., \& Mamolo, M. (2014). Quantifying policy trade-offs to support aging populations. Demographic Research, 30(1), 579-608. https://doi.org/10.4054/ DemRes.2014.30.20

Turner, J. A. (2013). How does social security work? Congressional Budget Office, 0-18. Retrieved from https://www.jstor.org/stable/j. ctvh4zdxx.4

Veen, R. Van Der. (2012). Chapter Title : Introduction Book Title: The Transformation of Solidarity Book Subtitle: Changing Risks and the Future of the Welfare State Book Editor ( $s$ ): Romke van der Veen, Mara Yerkes, Peter Achterberg Published by Amsterdam University Press. (Welfare State Risk), 14-15. Retrieved from https://www.jstor.org/stable/j.ctt46mw53.4

Wandner, S. A. (2018). Why the Unemployment Insurance Program Needs to Be Reformed. Unemployment Insurance Reform: Fixing a Broken System, 1-21. https://doi. org/10.17848/9780880996532.ch1

Watson, A. (2012). 12. Building Social Welfare in China: the economy. 265-287. Retrieved from https://www.jstor.org/stable/j.ctt24hd16.19 